Blockchain, Cryptocurrencies and Distributed Organizations

\author{
Research Article
}

\title{
Cryptocurrencies for Microfinance
}

Lucas Lopes Ferreira Souza ${ }^{1}$ Ana Augusta Ferreira de Freitas ${ }^{2}$ Jerffeson Teixeira Souza ${ }^{2}$ Samuel Façanha Câmara ${ }^{2}$

\footnotetext{
${ }^{1}$ Universidade de Fortaleza, Fortaleza, CE, Brazil. ${ }^{2}$ Universidade Estadual do Ceará, Fortaleza, CE, Brazil.
}

Received 26 June 2020. This paper was with the authors for three revisions. Accepted 31 October 2021. First published online 11 November 2021.

Editors-in-Chief: Carlo Gabriel Porto Bellini (DD (Universidade Federal da Paraíba, Brazil); Ivan Lapuente Garrido (D) (Universidade do Vale do Rio dos Sinos, Brazil)

Guest Editors: Jorge Renato Verschoore (iD) (Universidade do Vale do Rio dos Sinos, Brazil);

Eduardo Henrique Diniz (D) (Fundação Getúlio Vargas, EAESP, Brazil);

Ricardo Colomo-Palacios (iD) (Østfold University College, Norway)

Reviewers: Two anonymous reviewers

Editorial assistants: Kler Godoy and Simone Rafael (ANPAD, Maringá, PR, Brazil) 


\section{ABSTRACT}

The objective of microfinance is to provide services to create economic support for borrowers, so they can improve their social condition through entrepreneurial activity. Notwithstanding, credit alone is not sufficient to raise an individual out of poverty. In addition to credit, microfinance institutions can assist by providing professional and management courses, consultancies, financial assistance, and by the formation of solidarity groups. To suggest a way to achieve the microfinance goal, the aim of this article is to propose a cryptocurrency model and an artifact that can contribute to the microfinance environment. This will be supported by a cryptocurrency model and platform based on the design science research methodology. This essay shows that three agents can benefit from the cryptocurrency model: borrowers, microfinance institutions, and educational institutions. Furthermore, the results show that a new market can develop from this model with a viable platform to support the relationship between these agents.

Keywords: microfinance; cryptocurrency; design science research methodology

JEL Code: G210 


\section{INTRODUCTION}

Microfinance has grown rapidly over the past 30 years (Field, Pande, Papp, \& Rigol, 2013; Garikipati, 2017; Newman, Schwarz, \& Ahlstrom, 2017), becoming one of the main sources of entrepreneurship financing, notably in poor countries or emerging economies (Dutta \& Banerjee, 2017; Newman, Schwarz, \& Borgia, 2014; Shahriar, Schwarz, \& Newman, 2016).

Microfinance involves various services, such as credit, training, transfer services, savings, insurance, mortgages, and retirement plans, all on a small scale (Bateman \& Chang, 2012; Garikipati, 2017; Khavul, 2010). The main reason why these services are offered on a small scale is that the target audiences, who live in poverty or are excluded from the formal banking system, are unable to obtain loans from traditional banks because they cannot offer warranties, and, in many cases, conduct informal business (Bateman \& Chang, 2012; Chen, Chang, \& Bruton, 2017; Garikipati, 2017). Therefore, the objective of microfinance is to provide these services to create economic support for borrowers to enable them to improve their social condition through entrepreneurial activity (Bateman \& Chang, 2012; Chliova, Brinckmann, \& Rosenbusch, 2015; Cull \& Morduch, 2018; Khavul, 2010; Newman et al., 2014).

Credit is the main service of microfinance, and it is vital to the development of microentrepreneurs. Although the monetary value is small, it is sufficient to enable an entrepreneur to develop a business (Banerjee, Breza, Duflo, \& Kinnan, 2017; Chliova et al., 2015; Cull \& Morduch, 2018). Notwithstanding the recognition that credit alone is not sufficient to raise an individual out of poverty, it is understood that credit is essential and can provide relief by enabling entrepreneurs with the capacity to expand their businesses (Newman et al., 2017). In addition to credit, microfinance institutions can assist by providing professional and management courses, consultancies, financial assistance, and through the formation of solidarity groups (Samer et al., 2015).

One of the main factors that have impacted the growth of microfinance is its methodology, which is based on the assumption that microfinance, which is aimed at groups of poor people and offers attractive interest rates, is a viable solution for individuals to escape from poverty (Hermes, Lensink, \& Meesters, 2011; Miled \& Rejeb, 2015; Samer et al., 2015). In numerical terms, it has been estimated that, by 2014, approximately 130 million people had benefited directly and more than 370 million indirectly from microfinance; this means that, in total, more than 500 million people had benefited from this service by 2014 (Kagan, 2018).

However, the International Finance Corporation (IFC) (2016) reported that, until that date, only $20 \%$ of the target audience, comprised of 3 billion people, had been reached. By 2012, the microfinance industry had already processed more than US\$ 40 billion (Garikipati, 2017). From the aforementioned information, it is evident that microfinance is an important tool to combat poverty in a market that still has great potential for exploration and expansion (Jaiyeoba, Adewale, \& Ibrahim, 2018; Newman et al., 2014).

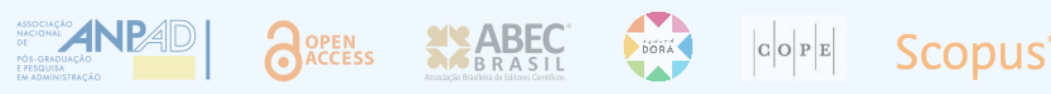


It is expected that the financial services offered by microfinance institutions (MFIs) will alleviate poverty in the world, and an economic and social transformation will occur not only in the lives of the participants but also in all the regions where these MFIs operate (Morduch, 1999). The impact on these regions is derived from the actions of entrepreneurs who own businesses or intend to start one and are financed by microfinance, thus acting on the economy of the region (Shahriar et al., 2016).

Therefore, the mission of microfinance is to provide credit and other banking services to the poor excluded from the banking system, so they can improve their living conditions (Mersland \& Strøm, 2010). However, this is only one part of the equation. The other part is related to the financial gains of the MFIs, which must achieve financial efficiency (Ghosh \& Guha, 2017; Mersland \& Strøm, 2010; Morduch, 1999). This subject has been widely discussed in the literature, since it is estimated that only $59 \%$ of these institutions are sustainable (Mersland \& Strøm, 2010). The ones that are not sustainable need subsidies and donations, or they operate at a loss (Morduch, 1999).

Moreover, microfinance must achieve positive results for two reasons: social gain and financial gain (Jaiyeoba et al., 2018). Thus, it should improve the life condition of the credit borrowers while profit for the MFIs is feasible (Ghosh \& Guha, 2017). When this result is achieved, it is defined as a win-win situation or dual objective (Morduch, 1999).

However, there are authors who claim that microfinance institutions are growing wealth by exploiting the poor (Bateman \& Chang, 2012), and this is not the purpose of microfinance (Cull $\&$ Morduch, 2018). Thus, what constitutes a fair level of profit for the microfinance institutions is being questioned (Hudon, Labie, \& Reichert, 2020). According to Hudon, Labie and Reichert (2020), four aspects must be observed: (a) whether the MFI is making a profit; (b) whether there is social gain; (c) whether the amount paid by the borrowers is abusive; and (d) what is done with excess profit. When these four factors are aligned without any overlap, it can be concluded that the MFI's level of profit is fair.

Although there are several studies discussing the effectiveness of microfinance (Banerjee, Duflo, Glennerster, \& Kinnan, 2015; Hermes et al., 2011; Souza, Bassi, \& Freitas, 2021), some authors argue that it is possible to improve the effectiveness of microfinance through technology, although there is an insufficient number of studies on this topic (Ashta \& Herrmann, 2021; Elliot, Ngugi, \& Malgwi, 2018; Rakkini \& Geetha, 2021). Technology has allowed the banking system to achieve improved results for both financial institutions and consumers (Prisco \& Strangio, 2021). Therefore, it is expected that microfinance might also benefit from the use of technology in its operations (Ashta \& Herrmann, 2021). However, there is little research on the use of technologies, their possibilities, and their impacts on microfinance. Based on technology, it is possible to increase the number of clients, monitor them to reduce the asymmetry of information, and provide credit through digital means, thus reducing the associated costs. In this context, new technologies have been researched, both in the banking sector in general and in the context of microfinance (Milana \& Ashta, 2020). For the purpose of this project, the potential

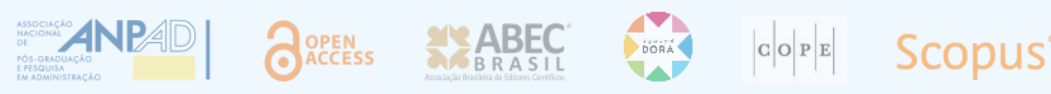


of blockchain and cryptocurrencies as tools that can expand the capacity of MFIs to meet their goals is highlighted (Liu, Li, \& Wang, 2020; Siqueira, Honig, Mariano, \& Moraes, 2020).

To achieve the alignment of the aspects suggested above, this article aims to propose a cryptocurrency model and an artifact that can contribute to the microfinance environment. The cryptocurrency model that will be proposed is based on the design science research (DSR) methodology (Hevner, 2007), and a platform will thereafter be presented as an initial solution. Research done by Siqueira, Honig, Mariano and Moraes (2020) already suggests the use of cryptocurrencies for the Brazilian microfinance environment, and the results of this research have shown that a community currency benefits stakeholders' relationships because it creates a sense of community. Furthermore, Al-Saqaf and Seidler (2017) have emphasized the need for further studies that address the use of blockchain technology as a generator of social impact, and Ashta and Herrmann (2021) have suggested experimentation in credit scoring techniques.

To contribute to the research, this article presents a proposal of a model and the design of a platform that follows the evolution of microfinance credit borrowers, rewarding them with bonuses for good behavior. Underlying the proposal is the idea that, by making better decisions, beneficiaries of microcredit will be able to improve their social condition. The cryptocurrencybased model is presented as a coherent option, since it includes tools to conduct safe, transparent, and low-cost monitoring.

\section{MICROFINANCE AND TECHNOLOGY}

Microfinance gained visibility from the model implemented by Yunus at Grameen Bank (Mia, Lee, Chandran, Rasiah, \& Rahman, 2019). Jawadi, Jawadi, and Dechamps (2010) warn that managing all the financial and microcredit demands of small companies supported by microfinance may not be possible without significant access to sophisticated information and communication technologies (ICT). In this arena, there are indications of new technologies, such as mutual support systems, interdependent credit systems, village savings, credit banks, and credit systems for microenterprises (Jawadi, Jawadi, \& Dechamps, 2010; Khavul, 2010). In all of these, the role of technological innovations in enabling new means of performing transactions, monitoring customers, and contributing to microfinance is highlighted (Milana \& Ashta, 2020; Singh \& Padhi, 2015).

As in the banking sector, the microfinance sector is impacted by technological changes, and these changes directly contribute to the ability to reach out and achieve the win-win situation (Milana \& Ashta, 2020; Singh \& Padhi, 2015). Some of these technologies are related to the development of fintechs (Liu et al., 2020) - including e-banking, apps, and mobile payment - that are already being used by MFIs (Elliot et al., 2018; Jawadi et al., 2010). In addition, the following technological innovations stand out in the sector: online lending, crowdfunding, transaction and payment terminals, personal finance management, digital currency and cryptocurrency, mobile points of sale, robo-advisors, e-banking, and insurtech (Liu et al., 2020).

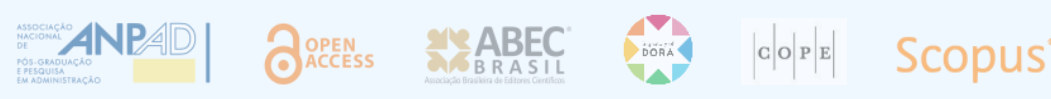


With new technologies, it has been possible to expand the role of MFIs, and they now have greater capacity for managing and monitoring clients; consequently, they can manage the risks to provide more scalability and serve more people in a larger geographic space while reducing costs (Singh \& Padhi, 2015). In addition, it is noteworthy that there has been an improvement in employee productivity, information management, and the speed of evaluation and decisionmaking (Singh \& Padhi, 2015). Elliot, Ngugi, and Malgwi (2018) note that only through the use of mobile banking technology is it possible to expand the scale and scope of microfinance; do credit analysis with results in real time; expand CRM use; assess and monitor the performance of the borrowers; and realize loans in solidarity groups. Finally, Liu, Li and Wang (2020) confirm the role of these technologies in the financial sector and highlight the importance of blockchain and cryptocurrencies in shaping new financial platforms.

In fact, blockchain and cryptocurrencies have been identified as the next technologies to be incorporated into financial institutions and, eventually, into microfinance (Liu et al., 2020; Siqueira et al., 2020). These technologies are important because they will result in more security, decreased costs, greater control and monitoring, and more transparency. These characteristics are essential in microfinance for a win-win relationship between MFIs and borrowers. Data security is vital for borrowers if they are to rely on MFIs. Lower costs may result in new products and an improvement in the relationship between MFIs and borrowers. Control over operations and monitoring of borrowers are important for the formulation of new strategies and guidelines (Souza, Bassi, \& Freitas, 2019). Finally, transparency is essential to show society how MFIs work and what their results are. This research shows how cryptocurrencies can be used to achieve the win-win situation in the context of microfinance and how, through the DSR model, it is possible to combine theory with the construction of a platform that has a practical purpose.

\section{METHODOLOGY}

The methodology used in this article is based on the design science research (DSR) methodology, commonly used in information systems (Gregor \& Hevner, 2013; Peffers, Tuunanen, Rothenberger, \& Chatterjee, 2007), and production engineering (Aken, Chandrasekaran, \& Halman, 2016; Lacerda, Dresch, Proença, \& Antunes, 2013). This methodology focuses on demonstrating relevance and rigor in creating research that utilizes scientific knowledge to design and build artifacts to solve problems (Costa \& Lima, 2011; Lacerda et al., 2013). Artifacts involve the use of information technology, conceived as a complex and changing combination of people and technology, which can be considered as material and cultural properties packaged in a socially recognizable form such as hardware or software (Dahlbom, 1996; Iivari, 2007; Orlikowski \& Iacono, 2001).

The purpose of the DSR methodology is to add knowledge to theory through empiricism and the development of artifacts, which is considered a pragmatic way to advance knowledge (Alturki, Bandara, \& Gable, 2012; Hevner, 2007). The difference is in the way the problem is approached. The DSR methodology focuses on finding solutions, while, in behavioral science, the focus is mainly on finding explanations and causalities (Aken, 2004; Alturki et al., 2012). Therefore, the

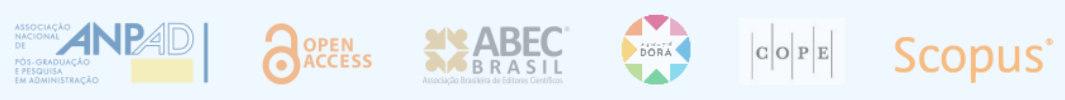


focus of the DSR methodology is to discover whether an artifact will provide utility (Hevner \& Chatterjee, 2010) - that is, whether it will impact the studied context and generate theoretical contributions that will, in turn, generate new ideas (i.e., concepts) (Alturki et al., 2012).

This cyclical behavior generated by the DSR methodology has led to the creation of the threecycle framework (Hevner, 2007; Hevner \& Chatterjee, 2010). The relevance cycle bridges the contextual environment of the research project and the design science activities. The rigor cycle connects the design science activities with the knowledge base, which consists of the scientific foundations, experience, and expertise that inform the research project. The central design cycle iterates between the core activities of building and evaluating the design artifacts and research processes (Hevner \& Chatterjee, 2010). For this study, the environment will be the context of microfinance, the DSR methodology will be the cryptocurrency model, and the proposed platform and knowledge base are built from the cryptocurrency literature (Figure 1).

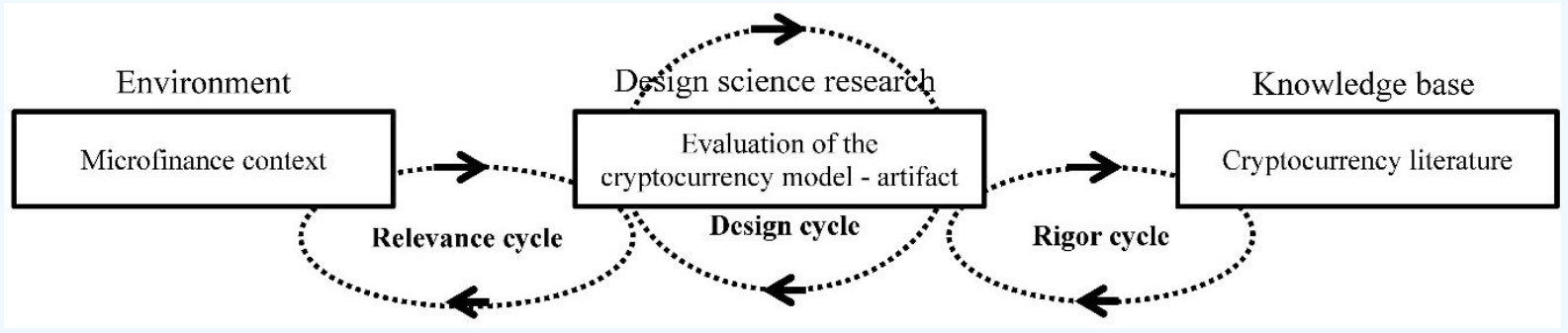

Figure 1. Design science research cycles - microfinance platform.

\section{ENVIRONMENT - MICROFINANCE}

There are several variables that influence the final outcome for a microfinance client. Some of these are the social, financial, and cultural context of the business; entrepreneurial skill; social ties; social capital; psychological capital; financial condition; sociodemographic and behavioral profile; and the orientation of future objectives (Bruton, Khavul, \& Chavez, 2011; Chliova et al., 2015; Newman et al., 2014; Van Rooyen, Stewart, \& De Wet, 2012). In addition, the importance of the products provided by the institutions should be highlighted, ranging from basic credit loans to training, courses, and other social, financial, and psychological support tools (Newman et al., 2014), as these indicate that the role of MFIs goes beyond merely providing credit (Morduch, 1999).

Therefore, it is believed that microfinance could have a much greater impact than just financially and that it can improve the lives of future generations because families would be able to afford superior food and education for their children with credit (Dutta \& Banerjee, 2017). Moreover, it has been demonstrated that analyses that go beyond the financial issues are important for evaluating improvement in the life conditions of the borrowers, which can come about through consumption, education, health, housing, freedom of choice, self-sufficiency, and gender equality (Banerjee et al., 2017; Cull, Demirgüç-Kunt, \& Morduch, 2018; Garikipati, 2017; Khavul, 2010).




According to Newman, Schwarz, and Borgia (2014), microfinance offers the poor an opportunity to face poverty, generate income, and take advantage of business opportunities. The authors argue that the granting of loans will also have a direct effect on entrepreneurial activity, increase financial capital, and, possibly, impact business results positively, thus generating psychological capital for clients.

Furthermore, Banerjee, Duflo, Glennerster and Kinnan (2015) and Banerjee, Breza, Duflo and Kinnan (2017) have demonstrated that microfinance can generate growth in a borrower's business and that the greater the entrepreneurial capacity of the individual, the more long-lived the results (Banerjee et al., 2017). Chliova, Brinckmann, and Rosenbusch (2015) have shown in a meta-analysis that microfinance provides individuals with the financial resources necessary to start, maintain, and develop their own ventures, which can improve financial well-being and lead to positive results in human development.

In addition, with the improvement in business, microfinance also enables improvements in household income and children's education (Dutta \& Banerjee, 2017). Access to microcredit also benefits the health and nutrition of families because of an increase in household income. As Wulandari and Kassim (2016) assert, in practice, microfinance not only reduces the incidence of poverty but also reduces its depth and severity. Furthermore, Donou-Adonsou and Sylwester (2016) have concluded that growth in microfinance loans impacts economic growth and total factor productivity in developing countries.

According to Samer et al. (2015), a survey conducted in Malaysia showed that microfinance has a positive impact on reducing poverty and increasing women's household income, especially in rural areas. The results of this study highlighted the importance of control variables that have a positive impact on the income of this group. For example, access to business training has a positive impact on women's household income. This indicates that business knowledge leverages the ability to make a profit and improve business revenue.

The results from the research reported here highlight the fact that access to microfinance brings about change for families. However, it cannot be expected that all transformations will be similar (Banerjee, Karlan, \& Zinman, 2015). This caveat is included because, despite the positive results produced by microfinance, many researchers cast doubts on the capacity of microfinance to create sustainable entrepreneurship (Bateman \& Chang, 2012; Field et al., 2013; Karlan \& Zinman, 2012).

For example, although entrepreneurship requires human and financial capital to create ventures, poor people in impoverished contexts may not have enough education, experience, and skills to develop ventures or overcome the inevitable barriers (Amine \& Staub, 2009; Dupas \& Robinson, 2013; Staniewski, 2016). This lack of skills potentially causes the poor to be confined to subsistence activities rather than engaging in entrepreneurial activities. Another potential problem for microfinance in the development of entrepreneurship is that many credit borrowers use loans to meet their immediate consumption needs rather than investing in value-adding activities, and they therefore cannot find capital to repay the loan (Chen et al., 2017; Karlan \&

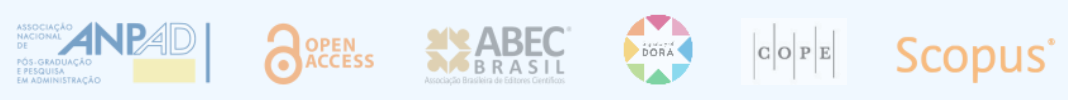


Zinman, 2012). Thus, the role of MFIs goes beyond only the provision of credit, and the need for them to provide other means to enable entrepreneurs to become professional and thus improve their social condition (Banerjee et al., 2017; Banerjee, Duflo, et al., 2015), is highlighted.

In this context, research by Souza, Bassi and Freitas (2019) and Souza, Bassi and Freitas (2021) have demonstrated that customers have differing conditions and characteristics, and it is thus important that institutions use a variety of strategies. To meet the diversity of needs in this environment, the DSR methodology is proposed as a means of creating a model for microfinance. Finally, for the DSR methodology, people are microfinance clients and MFIs and organizational systems are the entire market that microfinance is involved in. Technical systems are based on the way that microfinance works. To assist MFIs in achieving their dual objective, this research presents a platform based on cryptocurrencies.

\section{KNOWLEDGE BASE - CRYPTOCURRENCIES}

Cryptocurrencies are digital assets usually created with the main purpose of serving as a means of exchange. However, like money, those assets could conceivably also act as store of value and unit of account. Therefore, they have become a popular payment method due to their low cost, high transfer speed, and decentralized tracking network that provides secure transactions and a high degree of anonymity (Tredinnick, 2019). Cryptocurrencies remain secure with cryptography because they use blockchain, which is based on cryptography (Krueckeberg \& Scholz, 2019). The distributed nature of blockchain makes it impossible to change any record without affecting subsequent records, which makes it transparent and robust enough to be the basis of a monetary system (Krückeberg \& Scholz, 2019; Tredinnick, 2019).

Tredinnick (2019) has suggested four advantages of the use of cryptocurrencies: (a) a lower transaction cost due to the lack of a centralizing agent and because the system is secure; (b) faster processing of transactions that occur in real time; (c) the possibility of global inclusion, since they can be used worldwide and do not incur exchange costs; and (d) the possibility of tracking and thus stopping fraudulent transactions.

An important mechanism for manipulating cryptocurrencies is smart contracts, which are digital contracts that execute their own terms once certain conditions related to the agreement have been met. Therefore, smart contracts not only register agreements between parties but can also enforce those agreements (Tredinnick, 2019). It is possible that, through the use of smart contracts, cryptocurrencies can program human behavior through incentives and the suggestion that a solution can be found (Kim \& Chung, 2019). Devine, Jabbar, Kimmitt, and Apostolidis (2021) suggest that, through smart contracts, it is possible to offer greater transparency and trust and thus generate better results for MFIs from both a social and economic point of view.

Cryptocurrencies have become a tool with high potential for microfinance, as they can allow MFIs to keep track of borrowers, helping them to make the best decisions (Seyedsayamdost \& Vanderwal, 2020; Siqueira et al., 2020). Compared to other solutions, cryptocurrencies have the

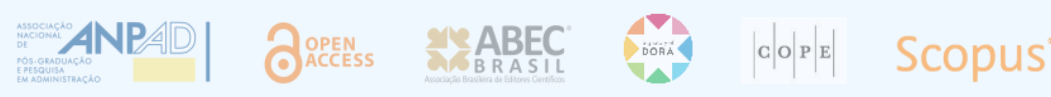


advantage of being a more complete package at a lower cost, since they have more features. Among these features, the following are notable: transparency, security, immutability, and decentralization (Devine, Jabbar, Kimmitt, \& Apostolidis, 2021; Hughes, Park, Kietzmann, \& Archer-Brown, 2019; Morkunas, Paschen, \& Boon, 2019; Rakkini \& Geetha, 2021).

Security is ensured by the fact that information is decentralized, which creates a lower risk of hacker attacks (Hughes et al., 2019). In addition, the information is recorded (Hughes et al., 2019). This is important for MFIs to monitor the development of borrowers and, in addition, reduce the risk of information asymmetry (Elliot et al., 2018; Nayak \& Silva, 2019). The implementation and transaction costs are similar to those of other platforms; however, the package that the cryptocurrency provides for the same cost delivers greater advantages. For instance, most cryptocurrencies are completely transparent and trackable while still being entirely anonymous in the sense that one can hold a cryptocurrency address without revealing anything about one's identity. In addition, the process is transparent, which facilitates regulatory processes. Finally, this technology is considered easy to use, as it is possible to gain the benefits of cryptocurrencies with the use of a smartphone. Previous research has already shown that smartphones are a technology that is accessible to borrowers (Elliot et al., 2018).

Finally, it is noteworthy that a facility resulting from the use of cryptocurrencies relates to smart contracts that are activated as soon as the contract is completed. In the model suggested in this article, upon achieving certain goals, beneficiaries are awarded with cryptocurrencies, and smart contracts facilitate this control, since they are already automated and do not require the release of any part for the benefit to be delivered and received.

\section{DESIGN SCIENCE RESEARCH - MODEL AND PLATFORM}

This section presents the cryptocurrency model and platform.

\section{Cryptocurrencies model}

The proposed model (Figure 2) in this project is built on the idea that credit borrowers in microfinance programs, after demonstrating good behavior like achieving goals established by the MFI, are rewarded with cryptocurrencies that can be used in three ways: (a) for management, professional, and other types of courses that can leverage the enterprise through the professionalization of business practices; (b) for exchanges between MFI credit borrowers, who will be able to help each other by buying from each other, thus using cryptocurrencies as a way to encourage mutual work and increase trust among borrowers and between the borrowers and the MFI; and (c) in exchange for bonuses or credit benefits in the program itself. 


\section{Microfinance Institution}

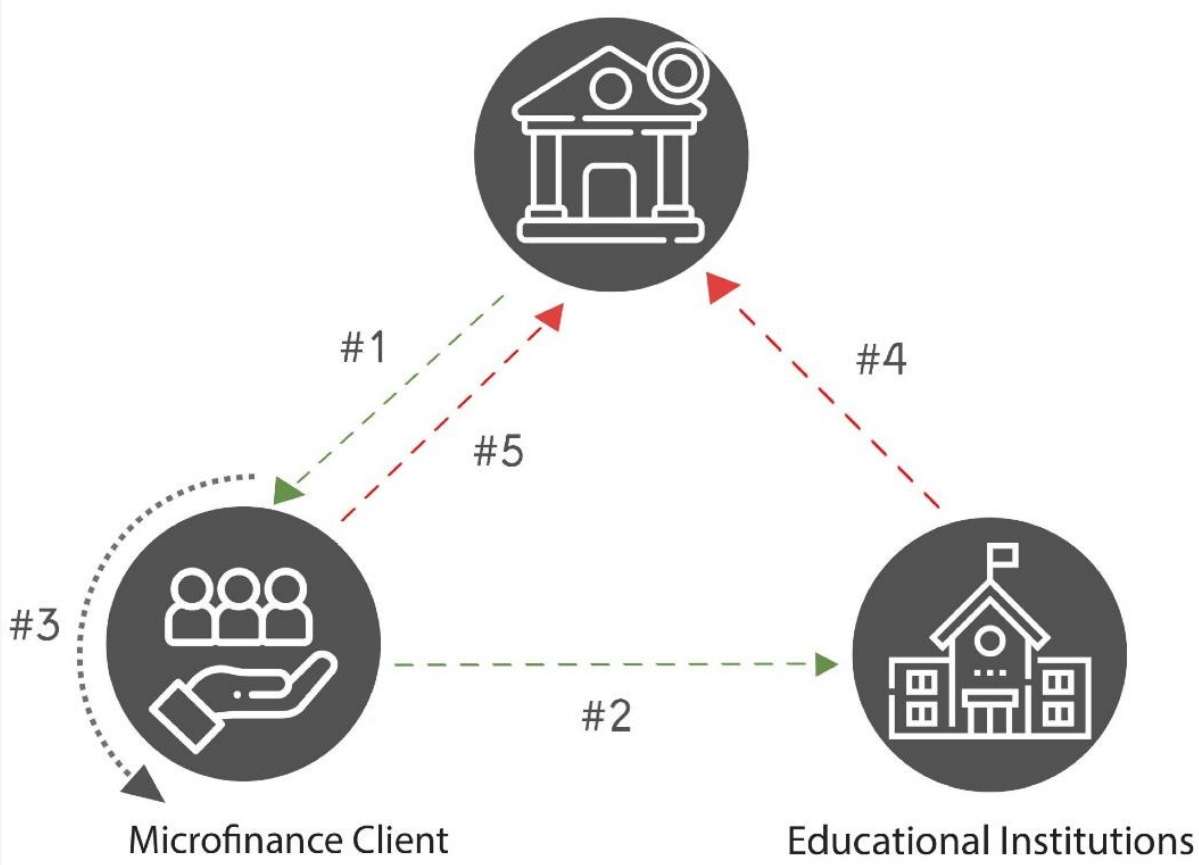

Figure 2. Cryptocurrency model.

\section{Microfinance institution $\rightarrow$ Microfinance client}

In this relationship, the MFI will provide borrowers who achieve the goals set by the MFI with cryptocurrencies. These goals might be, for example, the renewal of the operation, on-time payments, invitations to new members to join the program, or support for schoolchildren. It is important to note that the objective of these goals is to reward positive behaviors that establish win-win situations between the MFI and the credit borrower.

It is understood that borrowers who have long-term banking relationships enjoy numerous qualitative benefits arising from the lasting relationship with the MFIs because, with long-term relationships, there is a decrease in the monitoring of costs and risk, an increase in revenues and value loans, and improved confidence in the borrower's ability to make the best decisions regarding the loan. For the clients, these long-term relationships turn MFIs into continuous sources of capital, and, with increased confidence, interest rates may decrease and loan amounts increase (Souza et al., 2021; Souza, 2019).

\section{Microfinance client $\rightarrow$ Educational institutions}

Borrowers will be able to use cryptocurrencies in educational institutions to obtain professional training. The institutions will be accredited and will accept the coins as a form of complete or partial payment for the courses. 


\section{Microfinance client $\rightarrow$ Microfinance client}

In addition to increasing professionalization, it is expected that cryptocurrencies will be used as a way to develop credit borrowers' markets. Thus, customers will be able to use cryptocurrencies to purchase products or services from other borrowers. This will lead to an increase in the market, and the businesses of these borrowers will therefore improve. In addition, trust relations between the borrowers and the MFIs will increase. Finally, cryptocurrencies can be used as a form of payment among the members of the solidarity group, even to show conscientious payments, thus reinforcing social collateral. Participation in solidarity groups reinforces relational capital, especially in societies with weak institutional contexts, and relational capital assists in connecting people and improving information exchange (Newman et al., 2014). This relationship between borrowers will emphasize the sense of community suggested in the work of Siqueira et al. (2020). Moreover, in a related study, Cassar, Crowley, and Wydick (2007) used field experiments in several countries to illustrate how social cohesion and group homogeneity promote the repayment of loans at higher levels of trust than in society as a whole.

\section{Educational institutions $\rightarrow$ Microfinance institution}

Educational institutions would benefit from having students who want to improve their business skill. Borrowers need to improve managerial skill, but they do not have access. In this case, the courses would be paid for with cryptocurrencies that can be exchanged for money at the MFIs. In addition, educational institutions will gain social benefits by offering their products to entrepreneurs who require resources.

\section{Microfinance client $\rightarrow$ Microfinance institution}

If the MFI borrowers do not choose to enroll in a course or buy products or services from other institutions' partners and borrowers, there is the possibility of the MFI exchanging cryptocurrencies for bonuses that could be used for exemption from the credit opening rate or benefits in the form of credit, such as the possibility of obtaining a higher value loan or a lower interest rate.

In summary, the proposed model aims to benefit customers who demonstrate positive behaviors according to goals established by the MFIs and based on the cryptocurrencies that can only be used in the suggested establishments. Thus, the bonuses offered by the MFIs are for the purpose of assisting the entrepreneurs in their development and are based on guidelines established by the MFIs.

\section{The platform}

The developed platform aims to monitor microfinance clients and create a score for the client based on their results and the goals achieved, and the score is used to reward the client with cryptocurrencies that can be used in partner institutions, at the MFIs, or with other borrowers.

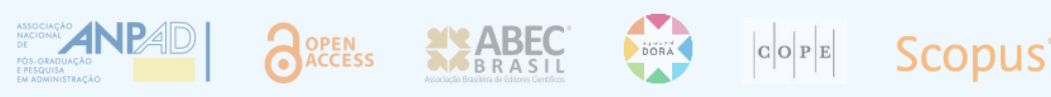


There are three stages in the development of this platform: the first is the dynamic market segmentation model, using the latent class Markov model (LCMM) technique to establish the classifier for the creation of the score (Souza et al., 2021; Souza, 2019). This step is important because the required goals cannot be the same for everyone, as each client has different needs and potential. The platform would use individualized data from each consumer to divide them into homogeneous groups, which would make it possible to establish goals according to the group to which the customer has been allocated. Furthermore, as the purpose is for these customers to develop, this division must be dynamic; that is, it should follow the development of credit borrowers, because customers could be allocated to different groups as time passes. The second stage is the relationship model, which is the platform where all agents will interact, and the third stage is the system architecture, which is a module for the use of blockchain technology in cryptocurrencies aimed at the connection between users, banking system, and partners.

\section{PRESENTATION OF THE PLATFORM DESIGN}

The platform is still under development, but there is already an artifact. The development is part of the DSR methodology. Currently, the data of borrowers and MFIs that are interested in accessing customers are being registered on the platform, and partners are being sought. The classifier and the dynamic tracking capability are ready. Since the goals are still to be defined by the MFIs, these have not yet been stipulated.

The scoring system to create a credit score for the borrowers was developed as a cryptocurrency with blockchain technology. The token was built according to the ERC-20 standard on the Ethereum blockchain with a smart contract written in the Solidity language. To access the contract, an own application programming interface (API) was developed with access to services for inclusion, alteration, and recovery of the borrower's score. The platform was developed in the Python language, which is globally recognized as the best language for artificial intelligence and machine learning, and the MySQL database, which is fast and versatile. It was tested in a virtual environment in two steps. The first step tested its initial functionalities, such as user registration, institution registration, and registration edition; in the second step, an anonymous database was inserted to test the algorithm. The blockchain used on the platform will be Ethereum, the coin will be Ether, and the token will be created by the MFI that chooses to use the platform. The next step is to test the platform with users.

The segmentation model ran exactly as predicted in the research with the software. The artifact was simple and intuitive for both the 'MFI' and the 'credit borrower' users (Figure 3). With few fields and a responsive layout that is capable of running on PCs, tablets, and cell phones, the user experience in entering data was less bureaucratic than expected, which means that the system is user-friendly for both users. The demonstrative segmentation model and the percentage of the numbers likely to migrate among groups can be visually and intuitively displayed by the financial institution that intends to assign the credit.

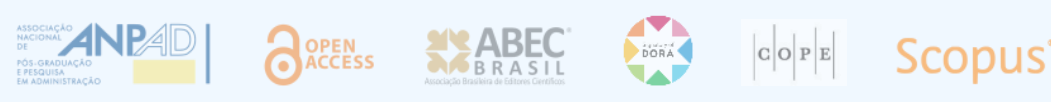




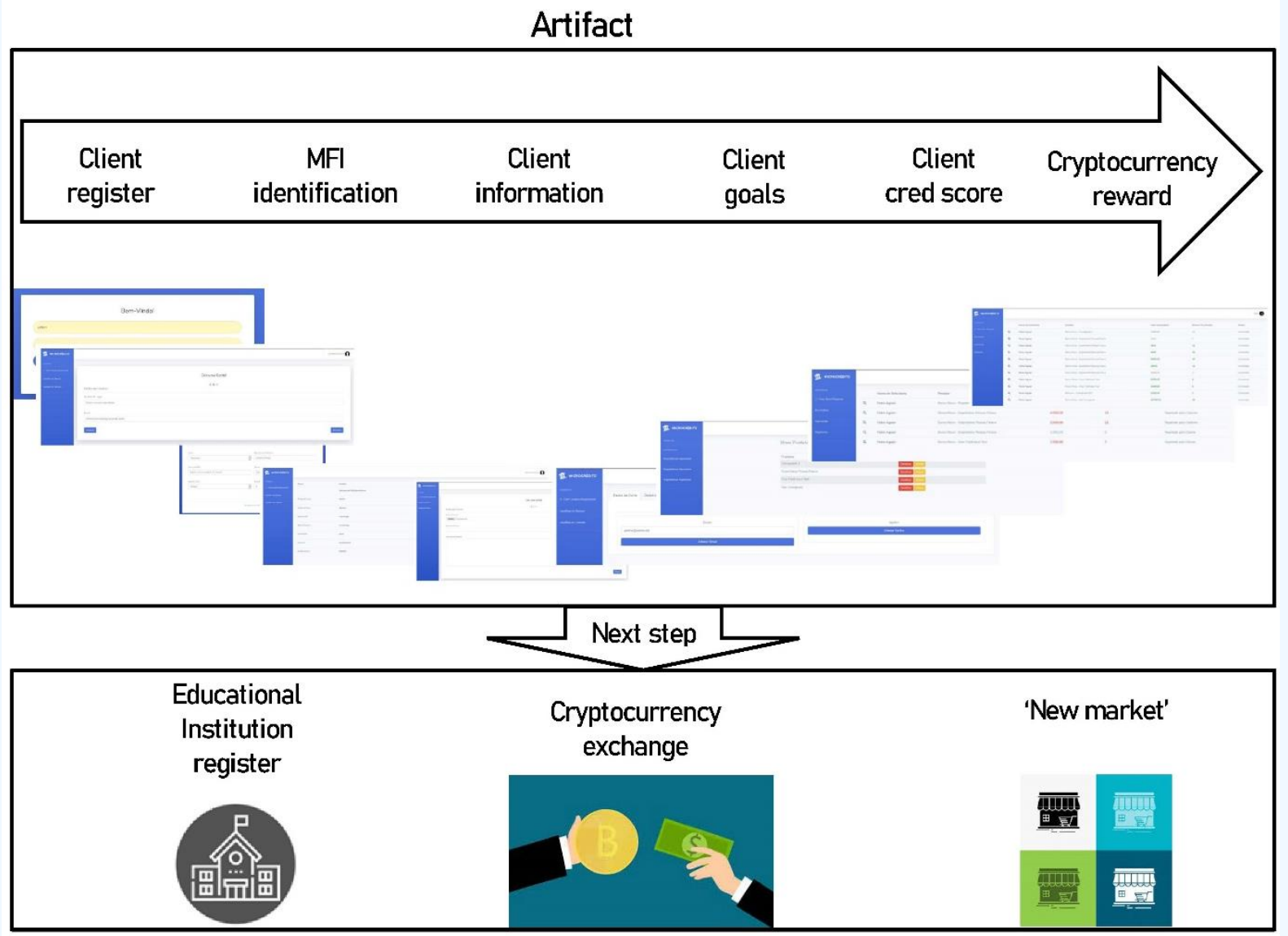

Figure 3. Platform environment.

As already noted, blockchain expands the MFl's capacity for monitoring, information management, reducing costs, and increasing scalability (Liu et al., 2020), which solves information asymmetry, one of the most significant problems that microfinance has to contend with (Elliot et al., 2018; Jawadi et al., 2010; Nayak \& Silva, 2019). Considering that all of these characteristics are vital to the advancement of microfinance (Jawadi et al., 2010; Singh \& Padhi, 2015), this research highlights the use of cryptocurrencies as a way for microfinance to broaden its horizons and offer new mechanisms to help combat poverty (Siqueira et al., 2020).

As stated by Jawadi et al. (2010), the main motivator for the implementation of a new technology should be to improve MFIs by decreasing costs and increasing performance. The model suggested in this research meets these requirements, introducing a platform where information asymmetry becomes smaller, since there is improved monitoring of the client that benefits those who exhibit positive behaviors. Costs will be lessened through reduced information asymmetry and the selected technology (Ethereum). In addition, the scope is extended by the fact that it will be possible to belong to this 'new market' with only access to a smartphone and the internet. In addition, a suggestion by Jawadi et al. (2010) that emphasizes the need for a scoring method to offer better services to customers was welcomed. 
Moreover, the proposed platform does not have any regulatory issues, as several models have already been implemented in the benefits arising from action markets, such as Pontos Multiplus, Dotz, and Petrobras Premmia. With this platform, the benefits will be MFI tokens that can be spent in certain locations and on certain products. In addition, there will be no difficulty in using the platform, since all the technology is accessible via smartphones. For a recent example, using the platform would be similar to making a transaction through PIX. Furthermore, as already mentioned, smartphones are an easily accessible technology that has helped borrowers combat poverty (Elliot et al., 2018).

Moreover, because it is a transparent technology, blockchain contributes to better monitoring of the results of microfinance. As Nayak and Silva (2019) have emphasized, the right balance between freedom for sustainable growth for MFIs and a correct dose of monitoring is necessary to maintain public confidence. Angelis and Silva (2019) claim that the next movement of blockchain will be the joint use of platforms such as this one with artificial intelligence. This is possible because the data is recorded and immutable, which makes it feasible to use artificial intelligence to monitor the evolution of borrowers and suggest future borrowers. The platform developed in this project creates scores and uses artificial intelligence to assess the possible classification of borrowers into groups based on their results. In this manner, the data will already be collected automatically, and the analysis of artificial intelligence can lead to suggestions for strategies for the borrowers.

\section{BENEFITS}

This section presents the benefits for all participants, namely the microfinance institution, customers (borrowers), and professional institutions. In general, the MFIs will benefit from the possibility of achieving greater social gain, since their objective of raising people out of poverty can be achieved in other ways, and there will be new ways to guide the clients to make the right decisions because of the targeted benefits (Morduch, 1999; Souza et al., 2019). In addition, the program will realize greater profit, and it is thus possible to share profits and surpluses in a fair and transparent manner (Hudon et al., 2020). Therefore, attitudes toward profit will no longer be questioned, since part of the profit will be reinvested in the clients. In addition, it is proposed that an own cryptocurrency is created to build a new market that will benefit customers and increase image gains for the institution (Siqueira et al., 2020). Finally, the benefits for clients and professional institutions are diverse, and no costs will be incurred.

\section{Benefits for the MFI}

Current literature recognizes the importance of microfinance and its role as a source of credit for borrowers to improve their living conditions. However, several authors question the profit earned by the MFIs and note the significant number of people who eventually suffer losses when participating in microfinance (Bateman \& Chang, 2012).

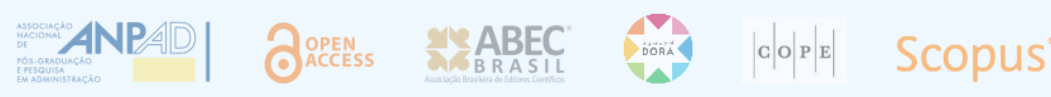


The profits obtained by MFIs are criticized by some authors (e.g., Bateman \& Chang, 2012; Chen et al., 2017; Karlan \& Zinman, 2012) who regard it as unethical to profit from the poor. They believe that excess profit or money should be reinvested in the borrowers. However, such an action is difficult to implement, as it is unclear how this reinvestment should be done. The microfinance model has an operational mode in which rates and values vary according to group, but a change in some of these values could negatively affect the entire model. In addition, another challenge is defining who will be selected to receive the benefits.

In the model proposed here, the MFIs would set goals to reward borrowers' positive behavior. Thus, the benefits could be distributed fairly. In addition, these goals must be established in consideration of both social and financial gain so that, when a goal is achieved, both the borrower and the MFI benefit. For example, when initiating a contract, the borrower pays a credit opening fee. If one of the goals is for the customer to start a new operation, an additional fee will be charged, and this will provide the institution with new revenue, a percentage of which can be utilized for a bonus for the customer in the form of cryptocurrency. These rewards can be established for anything that, in the MFI's understanding, will provide value to the borrower and the institution. Another possibility is in relation to prepayments; if a loan is paid in advance, the program perceives the remaining days as 'profit.' Part of this 'profit' can be returned to borrowers who pay the loans in advance.

Regarding the question of why cryptocurrencies should be provided, the literature includes several studies that indicate that microfinance is more harmful than favorable. This is because, in many cases, credit borrowers do not know how to use credit properly (Bateman \& Chang, 2012; Field et al., 2013; Newman et al., 2017).

An important point is that, in addition to credit, MFIs must provide other services, including courses, lectures, and consultancies. This is important to teach borrowers how to utilize their loans correctly. Thus, the literature emphasizes the necessity of conducting individual monitoring of customers, as each customer has unique needs (Cull \& Morduch, 2018; Souza et al., 2019). It is unfeasible for the MFIs to design specific strategies to accompany each client. In this context, cryptocurrencies are presented as an opportunity. Although it is not possible for the MFIs to outline specific strategies for each client, through cryptocurrencies it is possible transfer this task to the borrower. The borrower will only be able to use cryptocurrencies in establishments predefined by the MFI, so improved monitoring is therefore possible, and customers can be directed to specific actions.

Thus, if the borrowers behave positively, they will receive cryptocurrency and will only be able to use it for activities that the MFI considers to have the potential for development. Thus, the institution's profit or surplus can be distributed fairly, as the borrower will only receive deserved benefits, and the benefits will have positive results for the borrower. It is in this sense that the model suggested here should include professional education institutions, such as Sebrae and Senac. In addition, the use of cryptocurrencies among credit borrowers is presented as a possibility, thus reinforcing the market and enabling borrowers to assist each other (Siqueira et al., 2020).

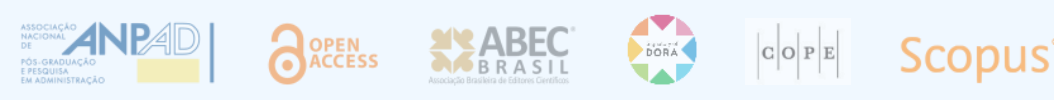


An integrative view of the proposal shows that the model provides a way for the MFIs to generate a positive image, since part of the profit is reinvested in customers. The model would also attract more customers, since borrowers participating in this 'new private market' could attract new sales.

\section{Benefits for the borrower}

The microfinance client is, by definition, in a financially fragile condition, and a considerable portion of his income is likely derived from informal micro-businesses (Garikipati, 2017). In most cases, this person does not possess either the educational level or managerial skills to manage money earned from business. Any earned money is typically used to sustain their family and reinvest in their business. In a few cases, profit from the business will be used to fund a course tuition, so that they can become professionals, or even to pay for their children to do a course to have more opportunities in the future. However, immediate needs are most important to them (Dutta \& Banerjee, 2017).

If MFIs reward these people for good behavior, demonstrating that good behavior will lead to some profit, it will be easier for borrowers to act correctly. In some cases, the borrower is not in a position to enroll in a course, as there are more urgent needs, so for this reason it is suggested that cryptocurrencies (i.e., prizes for good behavior) should be used to address urgent needs. It should be remembered that cryptocurrencies can be exchanged for benefits at educational institutions, when initiating a new loan, and for money when accumulating an amount predefined by the MFI.

The project presents several benefits for borrowers. Borrowers will conduct actions that will benefit them, and, when they achieve the goals, they will be able to enroll in courses that will professionalize them and enable them to improve their businesses at no cost. In addition, there is the possibility of selling to or buying products from other borrowers, which will assist both parties to increase their potential customer bases (Siqueira et al., 2020).

\section{Benefits for the educational institution}

Educational institutions that agree to participate in the arrangement will receive the value of the cryptocurrencies in cash and, in this way, will be paid the value of the course in the conventional way. The cryptocurrencies are only for the use of microfinance clients in specific locations, but educational institutions will be able to exchange them for cash.

In addition to receiving the full amount, the image of the educational institutions will be enhanced, as they will be serving a needy section of the public and will thus affirm their social role in the reduction of poverty. Furthermore, a previously unavailable market will become available to them, as people who could not ordinarily afford to enroll in courses will now be able to do so.

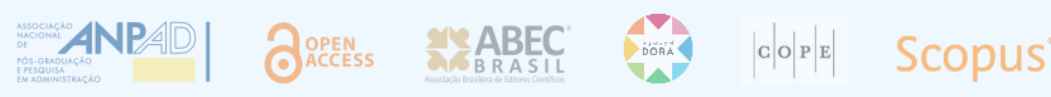




\section{Benefits for the 'new customer market'}

Cryptocurrencies can be used to fortify the microfinance client market (Siqueira et al., 2020). For example, there is a variety of services among the borrowers, so it is probable that borrowers will help each other by buying products or services from each other. The purchases can go beyond borrowers' products; the ideal is that they purchase raw materials for production. However, cryptocurrencies can also be used to meet immediate needs, such as food (Dutta \& Banerjee, 2017).

Therefore, cryptocurrencies will create a 'new private market,' in which only clients of the MFI can participate. This will increase customer confidence and may attract new borrowers; it will also increase trust among borrowers as they become acquainted with each other's businesses, and they can help each other more. Specifically, it is possible to imagine that solidarity groups will arise and become a way to receive money from any eventual debtor.

\section{DISCUSSION}

The provision of microcredits alone is rarely sufficient to alleviate poverty, but the coordinated actions of MFIs with other support initiatives can facilitate alleviation (Newman et al., 2017). The suggested model highlights the potential that cryptocurrencies have to change and bring benefits to an entire system that is already in operation. Cryptocurrencies can mitigate risks faced by both MFIs and borrowers. Furthermore, as cryptocurrencies are a tool that incorporates more security, reduced costs, greater control and monitoring, and more transparency, they make it possible to maximize the results obtained by helping MFIs achieve their dual objective (i.e., social and financial gains) (Devine et al., 2021). Cryptocurrencies and their practical use are still an incipient subject that deserves further study (Rakkini \& Geetha, 2021). This research proposes a platform that, in its test phase, has shown that the use of cryptocurrencies in microfinance is possible and that this can help borrowers to have better results. In the microfinance literature, there are several articles that focus on analyzing the results of microfinance (Van Rooyen et al., 2012). The present research advances such analysis by offering a tool and a model that contribute to the empirical field by providing a real solution, showing that microfinance has the potential to help poor entrepreneurs improve their social condition. Furthermore, there is a consensus in microfinance that credit alone is not enough to improve the living conditions of borrowers (Newman et al., 2017). The model suggested in this article points to a broader role for MFIs in that they can better track borrowers at no additional cost and reward borrowers who perform well. Through the use of cryptocurrencies, it is possible to guide borrowers to develop and thus achieve improvements in their businesses.

Furthermore, microfinance is focused on combating poverty (Rakkini \& Geetha, 2021), which is an issue that is relevant to the whole of society. Based on the model suggested here, it is possible to engage educational institutions that can help these borrowers develop professionally. Additionally, microfinance is based on social collateral, and its origin is linked to mutual assistance between borrowers (Morduch, 1999). The model suggests the generation of a 'new

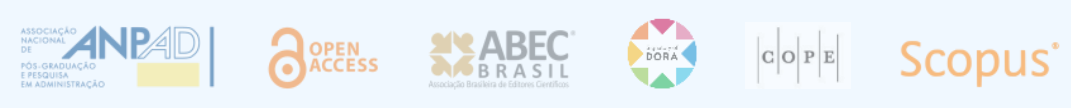


market' in which borrowers will be rewarded and help each other by buying from one another, emphasizing the social and collaborative role of each borrower.

Therefore, this article contributes to the microfinance literature by proposing a model that brings real contributions to the empirical field, expanding the scope of microfinance beyond the relationship between MFIs and borrowers and thus incorporating society into the system. The study also contributes to the literature on cryptocurrencies by highlighting their use in an approach different from the known bitcoins, presenting cryptocurrencies within the context of the management and monitoring of microfinance beneficiaries. The platform proposed here is aligned with the social business blockchain model proposed by Devine et al. (2021) and offers proposals that involve a credit score system and artificial intelligence capable of improving microfinance results.

\section{CONCLUSION}

This article aimed to propose a cryptocurrency model and an artifact that can contribute to the microfinance environment. The objective was achieved once the model proposal had been developed to the point where the main agents were involved, and the focus is to provide a winwin relationship. In addition, a platform that uses that cryptocurrency as an effective tool for the development of this model was presented.

The model presented includes the four aspects suggested by Hudon et al. (2020). In the proposed model, the MFIs' profit will be reinvested in cryptocurrencies that will be distributed to borrowers so they may have social gains. Thus, the MFIs would not have problems regarding excess profit and having to charge abusive rates. In addition, the MFIs will have a greater social role beyond only providing credit, as they will guide entrepreneurs to behave well and develop.

Although this research uses the DSR methodology to show robustness in the model and its application on a platform, the lack of empirical evidence is a limitation of the study. In addition, legislative issues and impacts on the financial market that could make the project unfeasible were not analyzed. Thus, a suggestion for future research is to focus on a legal analysis of the proposal and the empirical progress of the project. In addition, the model and platform presented here can be used for other types of market relations and for companies wanting to reward positive behavior in their employees or suppliers. Moreover, there is a glimpse of the possibility of the government rewarding citizens who exhibit good behaviors, such as reducing energy and water use and recycling or separating waste.

\section{REFERENCES}

Aken, J. E. V. (2004). Management research based on the paradigm of the design sciences: The quest for field-tested and grounded technological rules. Journal of Management Studies, 41(2), 219-246. https://doi.org/10.1111/j.14676486.2004.00430.x

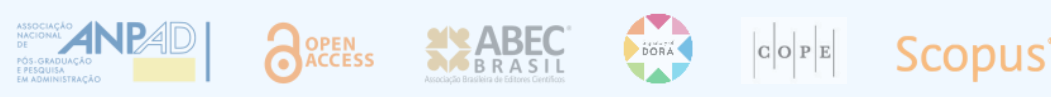


Aken, J. E. V., Chandrasekaran, A., \& Halman, J. (2016). Conducting and publishing design science research: Inaugural essay of the design science department of the Journal of Operations Management. Journal of Operations Management, 47-48, 1-8. https://doi.org/10.1016/j.jom.2016.06.004

Al-Saqaf, W., \& Seidler, N. (2017). Blockchain technology for social impact: Opportunities and challenges ahead. Journal of Cyber Policy, 2(3), 338-354. https://doi.org/10.1080/23738871.2017.1400084

Alturki, A., Bandara, W., \& Gable. (2012). Design science research and the core of information systems. In K. Peffers, M, Rothenberger, \& B. Kuechler (Eds.), Design science research in information systems: Advances in theory and practice (pp. 309-327). Cham: Springer. Retrieved from https://link.springer.com/chapter/10.1007/978-3-64229863-9_23

Amine, L. S., \& Staub, K. M. (2009). Women entrepreneurs in sub-Saharan Africa: An institutional theory analysis from a social marketing point of view. Entrepreneurship and Regional Development, 21(2), 183-211. https://doi.org/10.1080/08985620802182144

Angelis, J., \& Silva, E. R. (2019). Blockchain adoption: A value driver perspective. Business Horizons, 62(3), $307-314$. https://doi.org/10.1016/j.bushor.2018.12.001

Ashta, A., \& Herrmann, H. (2021). Artificial intelligence and fintech: An overview of opportunities and risks for banking, investments, and microfinance. Strategic Change, 30(3), 211-222. https://doi.org/10.1002/jsc.2404

Banerjee, A. V., Breza, E., Duflo, E., \& Kinnan, C. (2017). Do credit constraints limit entrepreneurship? Heterogeneity in the returns to microfinance [Working Paper n. 17-104]. Global Poverty Research Lab, India. Retrieved from https://www.innovationgrowthlab.org/content/do-credit-constraints-limit-entrepreneurshipheterogeneity-returns-microfinance

Banerjee, A., Duflo, E., Glennerster, R., \& Kinnan, C. (2015). The miracle of microfinance? Evidence from a randomized evaluation. American Economic Journal: Applied Economics, 7(1), 22-53. Retrieved from https://www.jstor.org/stable/43189512

Banerjee, A., Karlan, D., \& Zinman, J. (2015). Six randomized evaluations of microcredit: Introduction and further steps. American Economic Journal: Applied Economics, 7(1), 1-21. https://doi.org/10.1257/app.20140287

Bateman, M., \& Chang, H.-J. (2012). Microfinance and the illusion of development: From hubris to nemesis in thirty years. World Economic Review, 1(1), p. 13-36. Retrieved from https://econpapers.repec.org/RePEc:wea:worler:v:2012:y:2012:i:1:p:13

Bruton, G. D., Khavul, S., \& Chavez, H. (2011). Microlending in emerging economies: Building a new line of inquiry from the ground up. Journal of International Business Studies, 42(5), 718-739. https://doi.org/10.1057/jibs.2010.58

Cassar, A., Crowley, L., \& Wydick, B. (2007). The effect of social capital on group loan repayment: Evidence from field experiments. The Economic Journal, 117(517), F85-F106. https://doi.org/10.1111/j.14680297.2007.02016.x

Chen, J., Chang, A. Y., \& Bruton, G. D. (2017). Microfinance: Where are we today and where should the research go in the future? International Small Business Journal, 35(7), 793-802. https://doi.org/10.1177/0266242617717380

Chliova, M., Brinckmann, J., \& Rosenbusch, N. (2015). Is microcredit a blessing for the poor? A meta-analysis examining development outcomes and contextual considerations. Journal of Business Venturing, 30(3), 467-487. https://doi.org/10.1016/j.jbusvent.2014.10.003

Costa, S. E. G., \& Lima, E. P. (2011). Processos: Uma Abordagem da engenharia para a gestão de operações. In P.A.C. Couchick-Miguel (Org.), Metodologia de pesquisa em engenharia de produção e gestão de operações (pp. 63-72). Rio de Janeiro: Campus.

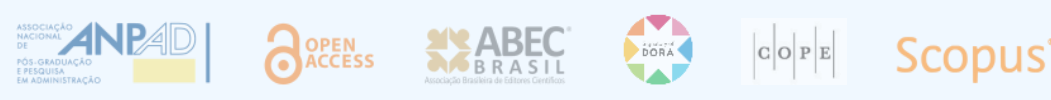


Cull, R., \& Morduch, J. (2018). Microfinance and economic development. In T. Beck \& R. Levine (Eds.), Handbook of finance and development (pp. 550-571). Cheltenham, UK: Edward Elgar Publishing.

Cull, R., Demirgüç-Kunt, A., \& Morduch, J. (2018). The microfinance business model: Enduring subsidy and modest profit. The World Bank Economic Review, 32(2), 221-244. https://doi.org/10.1093/wber/lhx030

Dahlbom, B. (1996). The new informatics. Scandinavian Journal of Information Systems, 8(2), 29-48. Retrieved from https://aisel.aisnet.org/sjis/vol8/iss2/3

Devine, A., Jabbar, A., Kimmitt, J., \& Apostolidis, C. (2021). Conceptualising a social business blockchain: The coexistence of social and economic logics. Technological Forecasting and Social Change, 172, 120997. https://doi.org/10.1016/j.techfore.2021.120997

Donou-Adonsou, F., \& Sylwester, K. (2016). Financial development and poverty reduction in developing countries: New evidence from banks and microfinance institutions. Review of Development Finance, 6(1), 82-90. https://doi.org/10.1016/j.rdf.2016.06.002

Dupas, P., \& Robinson, J. (2013). Savings constraints and microenterprise development: Evidence from a field experiment in Kenya. American Economic Journal: Applied Economics, 5(1), 163-92. https://doi.org/10.1257/app.5.1.163

Dutta, A., \& Banerjee, S. (2017). Microfinance and human development: A cross-generation study. In C. Neogi, A. Bhandari, \& S. Ghosh (Eds.), Women's entrepreneurship and microfinance (pp. 119-130). Singapore: Springer. https://doi.org/10.1007/978-981-10-4268-3_7

Elliot, E. A., Ngugi, B., \& Malgwi, C. A. (2018). Mitigating microfinance marketing channels inefficiencies with customerization of mobile technology. International Marketing Review, 35(4), 619-636. https://doi.org/10.1108/IMR-11-2015-0256

Field, E., Pande, R., Papp, J., \& Rigol, N. (2013). Does the classic microfinance model discourage entrepreneurship among the poor? Experimental evidence from India. American Economic Review, 103(6), 2196-2226. https://doi.org/10.1257/aer.103.6.2196

Garikipati, S. (2017). The impact of microfinance on poverty alleviation: Making sense of the evidence. In G. Giorgioni (Ed.), Development finance: Challenges and opportunities (pp. 189-206). London: Palgrave Macmillan.

Ghosh, C., \& Guha, S. (2017). Efficiency and mission drift-Debate revisited in Indian context. In C. Neogi, A. Bhandari, \& S. Ghosh (Eds.), Women's entrepreneurship and microfinance (pp. 97-117). Singapore: Springer.

Gregor, S., \& Hevner, A. R. (2013). Positioning and presenting design science research for maximum impact. MIS Quarterly, 37(2), 337-355. Retrieved from https://misq.org/positioning-and-presenting-design-science-researchfor-maximum-impact.html

Hermes, N., Lensink, R., \& Meesters, A. (2011). Outreach and efficiency of microfinance institutions. World Development, 39(6), 938-948. https://doi.org/10.1016/j.worlddev.2009.10.018

Hevner, A. R., \& Chatterjee, S. (2010). Design science research in information systems: Theory and practice. New York: Springer.

Hevner, A. R. (2007). A three cycle view of design science research. Scandinavian Journal of Information Systems, 19(2), 4. Retrieved from https://aisel.aisnet.org/sjis/vol19/iss2/4/

Hudon, M., Labie, M., \& Reichert, P. (2020). What is a fair level of profit for social enterprise? Insights from microfinance. Journal of Business Ethics, 162(3), 627-644. https://doi.org/10.1007/s10551-018-3986-z

Hughes, A., Park, A., Kietzmann, J., \& Archer-Brown, C. (2019). Beyond bitcoin: What blockchain and distributed ledger technologies mean for firms. Business Horizons, 62(3), 273-281. https://doi.org/10.1016/j.bushor.2019.01.002

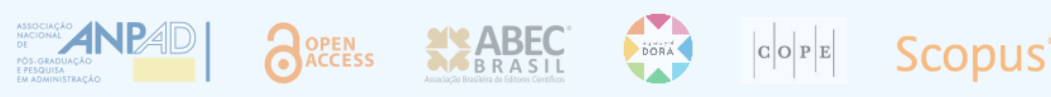


International Finance Corporation. (2016). IFC microfinance - Creating opportunity in emerging markets. Retrieved from: https://www.ifc.org/wps/wcm/connect/industry_ext_content/ifc_external_corporate_site/financial+institutio ns/resources/ifc+microfinance+_-+ creating + opportunity+in+emerging + markets

Iivari, J. (2007). A paradigmatic analysis of information systems as a design science, Scandinavian Journal of Information Systems, 19(2), 39-64. Retrieved from https://aisel.aisnet.org/sjis/vol19/iss2/5

Jaiyeoba, H. B., Adewale, A. A., \& Ibrahim, K. (2018). Measuring efficiencies of Bangladeshi and Indonesian microfinance institutions: A data envelopment analysis and latent growth curve modeling approach. International Journal of Bank Marketing, 36(2), 305-321. https://doi.org/10.1108/IJBM-01-2017-0009

Jawadi, N., Jawadi, F., \& Dechamps, V. (2010). European microfinance institutions and information and communication technologies: An empirical qualitative investigation in the French context. Journal of Electronic Commerce in Organizations, 8(3), 38-48. https://doi.org/10.4018/jeco.2010070104

Kagan, J. (2018). Microfinance. Investopedia. Retrieved from: https://www.investopedia.com/terms/m/microfinance.asp

Karlan, D. S., \& Zinman, J. (2012). List randomization for sensitive behavior: An application for measuring use of loan proceeds. Journal of Development Economics, 98(1), 71-75. https://doi.org/10.1016/j.jdeveco.2011.08.006

Khavul, S. (2010). Microfinance: Creating opportunities for the poor? Academy of Management Perspectives, 24(3), 5872. https://doi.org/10.5465/amp.24.3.58

Kim, M. S., \& Chung, J. Y. (2019). Sustainable growth and token economy design: The case of steemit. Sustainability, 11(1), 167. https://doi.org/10.3390/su11010167

Krückeberg, S., \& Scholz, P. (2019). Cryptocurrencies as an asset class. In S. Goutte, K. Guesmi, \& S. Saadi (Eds.), Cryptofinance and mechanisms of exchange (pp. 1-28). Cham: Springer. https://doi.org/10.1007/978-3-030-307387_1

Lacerda, D. P., Dresch, A., Proença, A., \& Antunes, J. A. V., Júnior. (2013). Design science research: Método de pesquisa para a engenharia de produção. Gestão E̊ Produção, 20(4), 741-761. https://doi.org/10.1590/S0104$530 \times 2013005000014$

Liu, J., Li, X., \& Wang, S. (2020). What have we learnt from 10 years of fintech research? A scientometric analysis. Technological Forecasting and Social Change, 155, 120022. https://doi.org/10.1016/j.techfore.2020.120022

Mersland, R., \& Strøm, R. Ø. (2010). Microfinance mission drift? World Development, 38(1), 28-36. https://doi.org/10.1016/j.worlddev.2009.05.006

Mia, M. A., Lee, H.-A., Chandran, V. G. R., Rasiah, R., \& Rahman, M. (2019). History of microfinance in Bangladesh: A life cycle theory approach. Business History, 61(4), 703-733. https://doi.org/10.1080/00076791.2017.1413096

Milana, C., \& Ashta, A. (2020). Microfinance and financial inclusion: Challenges and opportunities. Strategic Change, 29(3), 257-266. https://doi.org/10.1002/jsc.2339

Miled, K. B. H., \& Rejeb, J.-E. B. (2015). Microfinance and poverty reduction: A review and synthesis of empirical evidence. Procedia-Social and Behavioral Sciences, 195(31), 705-712. https://doi.org/10.1016/j.sbspro.2015.06.339

Morduch, J. (1999). The microfinance promise. Journal of Economic Literature, 37(4), 1569-1614. https://doi.org/10.1257/jel.37.4.1569

Morkunas, V. J., Paschen, J., \& Boon, E. (2019). How blockchain technologies impact your business model. Business Horizons, 62(3), 295-306. https://doi.org/10.1016/j.bushor.2019.01.009

Nayak, B. S., \& Silva, R. V. (2019). Evolution and effects of the legal and regulatory framework on microfinance in Brazil. Latin American Policy, 10(1), 162-179. https://doi.org/10.1111/lamp.12163

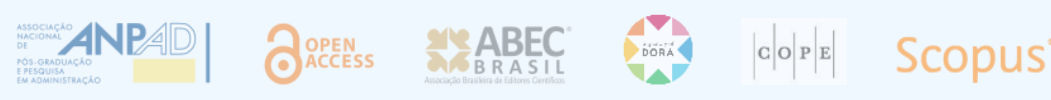


Newman, A., Schwarz, S., \& Ahlstrom, D. (2017). Microfinance and entrepreneurship: An introduction. International Small Business Journal, 35(7), 787-792. https://doi.org/10.1177/0266242617719314

Newman, A., Schwarz, S., \& Borgia, D. (2014). How does microfinance enhance entrepreneurial outcomes in emerging economies? The mediating mechanisms of psychological and social capital. International Small Business Journal, 32(2), 158-179. https://doi.org/10.1177/0266242613485611

Orlikowski, W. J., \& Iacono, C. S. (2001). Research commentary: Desperately seeking the "IT” in IT research-A call to theorizing the IT artifact. Information Systems Research, 12(2), 121-134. Retrieved from https://www.jstor.org/stable/23011075

Peffers, K., Tuunanen, T., Rothenberger, M. A., \& Chatterjee, S. (2007). A design science research methodology for information systems research. Journal of Management Information Systems, 24(3), 45-77. https://doi.org/10.2753/MIS0742-1222240302

Prisco, D., \& Strangio, D. (2021). Technology and financial inclusion: A case study to evaluate potential and limitations of Blockchain in emerging countries. Technology Analysis $\mathcal{E}$ Strategic Management. https://doi.org/10.1080/09537325.2021.1944617

Rakkini, M. J., \& Geetha, K. (2021). Blockchain-enabled microfinance model with decentralized autonomous organizations. In S. Smys, R. Panalisamy, A. Rocha, \& G. Beligiannis (Eds.), Computer networks and inventive communication technologies (pp. 417-430). Singapore: Springer.

Samer, S., Majid, I., Rizal, S., Muhamad, M. R., Sarah-Halim, \& Rashid, N. (2015). The impact of microfinance on poverty reduction: Empirical evidence from Malaysian perspective. Procedia-Social and Behavioral Sciences, 195, 721-728. https://doi.org/10.1016/j.sbspro.2015.06.343

Seyedsayamdost, E., \& Vanderwal, P. (2020). From good governance to governance for good: Blockchain for social impact. Journal of International Development, 32(6), 943-960. https://doi.org/10.1002/jid.3485

Shahriar, A. Z. M., Schwarz, S., \& Newman, A. (2016). Profit orientation of microfinance institutions and provision of financial capital to business start-ups. International Small Business Journal, 34(4), $532-552$. https://doi.org/10.1177/0266242615570401

Singh, V., \& Padhi, P. (2015). Information and communication technology in microfinance sector: Case study of three Indian MFIs. IIM Kozhikode Society \& Management Review, 4(2), 106-123. https://doi.org/10.1177/2277975215607251

Siqueira, A. C. O., Honig, B., Mariano, S., \& Moraes, J. (2020). A commons strategy for promoting entrepreneurship and social capital: Implications for community currencies, cryptocurrencies, and value exchange. Journal of Business Ethics, 166(4), 711-726. https://doi.org/10.1007/s10551-020-04578-2

Souza, L. L. F. (2019). Segmentação dinâmica do mercado das microfinanças (Doctoral dissertation). Universidade Estadual do Ceará, Programa de Pós-Graduação em Administração, Fortaleza, CE, Brazil. Retrieved from https://siduece.uece.br/siduece/trabalhoAcademicoPublico.jsf?id=88601

Souza, L. L. F., Bassi, F., \& Freitas, A. A. F. (2019). Multilevel latent class modeling to segment the microfinance market. International Journal of Bank Marketing, 37(5), 1103-1118. https://doi.org/10.1108/IJBM-05-2018-0132

Souza, L. L. F., Bassi, F., \& Freitas, A. A. F. (2021). Longitudinal analysis of microfinance borrowers in Brazil: A dynamic market segmentation. Journal of International Development, 33(6), 1063-1083. https://doi.org/10.1002/jid.3561

Staniewski, M. W. (2016). The contribution of business experience and knowledge to successful entrepreneurship. Journal of Business Research, 69(11), 5147-5152. https://doi.org/10.1016/j.jbusres.2016.04.095

Tredinnick, L. (2019). Cryptocurrencies and the blockchain. Business Information Review, 36(1), $39-44$. https://doi.org/10.1177/0266382119836314

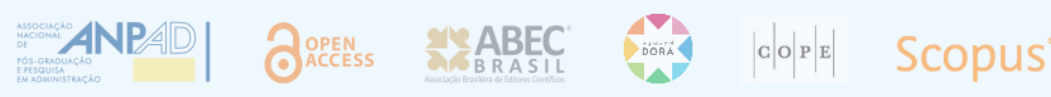


Van Rooyen, C., Stewart, R., \& De Wet, T. (2012). The impact of microfinance in sub-Saharan Africa: A systematic review of the evidence. World Development, 40(11), 2249-2262. https://doi.org/10.1016/j.worlddev.2012.03.012

Wulandari, P., \& Kassim, S. (2016). Issues and challenges in financing the poor: Case of Baitul Maal Wa Tamwil in Indonesia. International Journal of Bank Marketing, 34(2), 216-234. https://doi.org/10.1108/IJBM-01-2015-0007

\section{Authors' contributions}

$\mathbf{1}^{\text {st }}$ author: conceptualization (equal), investigation (equal), methodology (equal), project administration (equal), supervision (equal), validation (equal), writing-original draft (equal), writing-review \& editing (equal).

$2^{\text {nd }}$ author: conceptualization (equal), formal analysis (equal), project administration (equal), supervision (equal), validation (equal), writing-original draft (equal), writing-review \& editing (equal).

$3^{\text {rd }}$ author: conceptualization (equal), methodology (equal), supervision (equal), writing-review \& editing (equal).

$4^{\text {th }}$ author: conceptualization (equal), project administration (equal), supervision (equal), writing-review $\&$ editing (equal).

\section{Authors}

Lucas Lopes Ferreira Souza*

Universidade de Fortaleza, Programa de Pós-Graduação em Administração de Empresas

Av. Washington Soares, n. 1321, Edson Queiroz, 60811-025, Fortaleza, CE, Brazil

lucaslfsouza@unifor.br

(iD) https://orcid.org/0000-0001-9663-6086

\section{Ana Augusta Ferreira de Freitas}

Universidade Estadual do Ceará, Programa de Pós-Graduação em Administração

Av. Dr. Silas Munguba, n. 1700, Itaperi, 60714-903, Fortaleza, CE, Brazil

freitas8@terra.com.br

(iD) https://orcid.org/0000-0002-2741-6968

\section{Jerffeson Teixeira Souza}

Universidade Estadual do Ceará, Programa de Pós-Graduação em Administração

Av. Dr. Silas Munguba, n. 1700, Itaperi, 60714-903, Fortaleza, CE, Brazil

jeff@larces.uece.br

(iD) https://orcid.org/0000-0001-8361-4806

\section{Samuel Façanha Câmara}

Universidade Estadual do Ceará, Programa de Pós-Graduação em Administração

Av. Dr. Silas Munguba, n. 1700, Itaperi, 60714-903, Fortaleza, CE, Brazil

sfcamara2000@gmail.com

(iD) https://orcid.org/0000-0002-8333-6997

* Corresponding author

Peer review is responsible for acknowledging an article's potential contribution to the frontiers of scholarly knowledge on business or public administration. The authors are the ultimate responsible for the consistency of the theoretical references, the accurate report of empirical data, the personal perspectives, and the use of copyrighted material.

This content was evaluated using the double-blind peer review process. The disclosure of the reviewers' information on the first page is made only after concluding the evaluation process, and with the voluntary consent of the respective reviewers. 